\title{
ANALISIS KUALITAS PRODUK, DIVERSIFIKASI PRODUK, DAN KUALITAS PELAYANAN TERHADAP LOYALITAS PELANGGAN (Studi Kasus Di Pasar Gedhe Solo)
}

\author{
Faris Ardiansyah, ${ }^{1}$ Bambang Mursito, ${ }^{2}$ Siti Maryam ${ }^{3}$ \\ Universitas Islam Batik Surakarta \\ farizardiansyh@gmail.com
}

\begin{abstract}
Penelitian ini bertujuan untuk mengetahui pengaruh kualitas produk, diversifikasi produk dan kualitas pelayanan terhadap loyalitas pelanggan di pasar gedhe solo. Jenis penelitian ini menggunakan metode deskriptif kuantitatif.Populasi dari penelitian ini adalah pelanggan yang sedang berbelanja di Pasar Gedhe Solo dengan Purposiv sampling dengan convenience sampling untuk pengambilan sampelnya.Variabel dependen $(Y)$ dalam penelitian ini adalah loyalitas pelanggan. Variabel independen $(X)$ meliputi Kualitas Produk $\left(X_{1}\right)$ Diversifikasi Produk $\left(X_{2}\right)$ Kualitas Pelayanan $\left(X_{3}\right)$. Metode Analisi data menggunakan regresi linier berganda.Sedangkan untuk program data menggunakan IBM SPSS 21.0 statistik.Hasil analisis menunjukan bahwa terdapat pengaruh secara simultan dan signifikan variabel kualitas produk, diversifikasi produk dan kualitas pelayanan terhadap loyalitas pelanggan.model regresi dalam penelitian ini adalah $Y=67.130+(-0,677)+(-0,211)+(-0,364)+e$. Hasil koefisien determinasi menunjukan kualitas produk, diversifikasi produk dan kualitas pelayanan memiliki pengaruh sbesar 50,5 $\%$ terhadap loyalitas pelanggan di pasar gedhe solo
\end{abstract}

Keyword: loyalitas pelanggan, kualitas produk, diversifikasi produk, kualitas pelayanan

\section{PENDAHULUAN}

Setiap manusia atau konsumen memerlukan pemenuhan kebutuhan setiap harinya terutama adalah kebutuhan panganatau kebutuhan pokok. Sebelum adanya perkembangan modern seperti sekarang ini para konsumen dapat memenuhi kebutuhannya dengan membeli atau berbelanja di pasar-pasar tradisional. Namun seiring perkembangan modern kini pasar tradisional mengalami penyusutan konsumen karena adanya pesaing baru yaitu dari pasar modern seperti mall, supermarket, minimarket dan lain sebagainya. Pada pasar tradisional menampung banyak sekali para penjual dari golongan pedagang kecil menengah dan telah menjadi tulang punggung perekonomian para pedagang, penyusutan konsumen pada pasar tradisional ini tidak boleh terus menerus dibiarkan terkikis oleh semakin berkembangnya pasar modern karena didalam pasar tradisional melibatkan jutaan pedagang yang relatif dari golongan masyarakat menengah kebawah (Nurrohman, Maria \& Moh, 2016), apabila hal ini tidak mendapatkan perhatian khusus maka akan menimbulkan dampak sosial yang serius dan beperengaruh besar terhadap masyarakat karena dapat membuat para pedagang bangkrut karena kurangnya pendapatan dari menyusut nya konsumen yang mulai berpindah ke pasar modern kemudian mereka akan kehilangan mata pencaharianya dan mengakibatkan semakin menurunya kualitas hidup yang menjadi masalah bagi pemerintah maupun masyarakat sendiri (Sembiring, 2016). Itu lah mengapa pada hal ini pasar tradisional harus memahami perilaku dari para konsumenya agar pasar tradisional dapat bertahan dari ketatnya persaingan dalam memperebutkan konsumen yang mulai berpindah ke pasar modern dengan memahami konsumennya pasar tradisional dapat menarik para konsumen untuk menjadi pelanggan setia dalam memenuhi kebutuhan sehari-harinya dan dapat mempengaruhi konsumen lain agar membeli atau berbelanja dipasar tradisional yang sejalan dengan kegiatan pemasaran karena 
kegiatan pemasaran merupakan hal yang sangat berperan penting dalam suatu usaha dan digunakan sebagai sarana bagi para pengusaha untuk mempengaruhi para pelanggan dalam keputusan pembelian suatu produk agar badan usaha dapat berkembang dan mendapat keuntungan yang besar karena memahami para konsumennya merupakan faktor yang sangat penting terhadap keberlangsungan suatu usaha.

Sebagaimana fungsi dari pasar yang yang merupakan tempat fisik dimana para pembeli dan penjual bertemu (Gladis, Lotje\& Jantje, 2017) pasar tradisional juga merupakan sumber penghasilan oleh para pedagang kecil dan para petani berskala kecil untuk menjual barang dagangan maupun hasil panennya. Berbagai usaha dilakukan untuk meningkatkan lagi perkembangan pasar tradisional agar dapat menarik lagi para konsumen juga telah dilakukan seperti revitalisasi pasar-pasar tradisional agar terhindar dari kesan yang kurang menarik, kelemahan ataupun kekurangan dari pasar tradisional seperti kurangnya control kualitas barang yang dijual, kondisi pasar yang kumuh, higenis, kerapian pasar, dan juga kemasan produk yang dijual dinilai kurang menarik. Kelemahan dan kekurangan itu lah yang membuat para pelanggan mulai meninggalkan pasar tradisional, dengan semakin menyusutnya pasar tradisional membuat para pedagang banyak yang merasakan kerugian dibandingkan 5 tahun lalu dimana para penjual yang biasanya buka dari pagi sampai siang sudah dapat menghabiskan seluruh barang daganganya. Tentu saja dalam hal ini harus ada tindakan ataupun perhatian terhadap pasar tradisional, karena pasar tradisional merupakan tulang punggung perekonomian dimana pada pasar tradisional ini melibatkan jutaan pedagang yang relatif berskala kecil sehingga apabila semakin merosotnya pendapatan para pedagang dipasar tradisional ini dapat berdampak menjadi banyaknya jumlah pengangguran dari para pedagang yang gulung tikar karena tidak dapat bertahan ditengah persaingan usaha yang ketat dengan pasar modern. Dalam pengembangan ekonomi masyarakat pasar tradisional dianggap sebagai pusat jalur pemasaran hasil produksi kalangan pengusaha kecil maupun hasil pertanian dari masyarakat maka dari itu pentingnya loyalitas pelanggan karena merupakan kunci dari bertahannya pasar tradisional terhadap persaingan bisinis dengan pasar modern .Berkembangnya pasar-pasar di Indonesia dengan menjamurnya pasar modern yang menjadi pesaing ketat bagi pasar tradisional mengakibatkan penyusutan konsumen pada pasar tradisional yang sangat berpengaruh terhadap kegiatan ekonomi, namun penyusutan konsumen pada pasar tradisional ini terjadi bukan hanya karena berkembangnya pasar-pasar modern saja tetapi juga oleh factor lainya melainkan dari keadaan pasar tradisional sendiri seperti kondisi pasar tradisional yang identik dengan bau, kotor, becek dan lain sebagainya juga dalam hal kualitas barang dimana para penjual yang kedapatan memanipulasi produknya (Ariyanti, 2013). Dalam hal ini kebijakan pemerintah yang bersifat regulasi harus membuat beberapa kebijakan antara lain memperbaiki sarana prasarana pasar dan memperbaiki manajemen pasar tradisional agar pasar tradisional dapat bertahan dan menjaga kelangsungan hidupnya. Meskipun pada pasar tradisional memiliki harga yang lebih murah namun hal itu tidak menjadikan pasar tradisional mendapatkan kembali pangsa pasar nya yang mulai menyusut, maka dari itu pasar tradisional harus meningkatkan daya saing pasarnya agar pasar tradisional dapat bertahan dari berkembangnya pasar modern.Bertahannya pasar tradisional dalam mengembalikan konsumenya yang mulai merosot karena perkembangan pasar modern maka harus benar-benar memperhatikan loyalitas pelanggan karena loyalitas pelanggan merupakan tujuan dari pemasaran dan peningkatan citra pasar itu sendiri agar konsumen kembali berbelanja di pasar tradisional. Mempertahankan loyalitas pelanggan sebenarnya lebih sulit daripada mencari pelanggan baru di dalam dunia usaha sehingga pedagang lebih fokus kepada kepuasaan pelayanan daripada harus mempromosikan atau membuat iklan pada barang yang di jual oleh pengusaha atau pedagang.ini juga bisa disebut sebagai manfaat 
dari loyalitas pelanggan karena pedagang atau pengusaha tidak perlu mengeluarkan banyak anggaran dalam mempromosikan produk yang dijualnya (Ayuni, Hussein dan Hapsari, 2018)

Dibalik perkembangan pasar modern tidak sedikit juga masyarakat atau konsumen yang masih bertahan dan setia berbelanja di pasar tradisional walaupun smeakin lama semakin merosot karena adanya persaingan dengan pasar modern. Konsumen yang masih setia dengan pasar tradisional untuk memenuhi kebutuhannya dikarenakan alasan seperti harga yang terjangkau, keberagaman produk atau barang yang dijual oleh para pedagang, kualitas produk dari pedagang seperti sayuran maupun buah yang masih segar dan juga sistem tawar menawar yang merupakan ciri khas dari pasar tradisional. Konsumen dalam keputusan pembeliannya terhadap pasar tradisional juga dipengaruhi dari banyak nya jenis produk ataupun barang yang dijual di pasar tradisional karena konsumen cenderung lebih memilih pasar yang menjual dengan variasi barang yang banyak dan kualitas barang yang bagus, diharapkan para konsumen dapat memilih dan menentukan barang atau produk yang dijual di pasar tradisional untuk memenuhi kebutuhan hariannya (Nurrohman, Maria \& Moh, 2016). Sama halnya dengan keanekaragaman barang, kualitas pelayanan juga sangat berpengaruh penting terhadap konsumen yang berbelanja di pasar tradisional karena kepuasan pelayanan terjadi karena adanya interaksi antara produsen atau penjual dengan konsumen yang apabila konsumen puas dan senang terhadap kualitas pelayanan dari pedagang ataupun penjual maka konsumen akan melakukan pembelian ulang terhadap barang yang ditawarkan bahkan bisa mempengaruhi konsumen lain untuk berbelanja di tempat tersebut( Saputra, 2015). Kualitas pelayanan sendiri merupakan penentu utama dari kepuasan konsumen atau pelanggan karena kualitas pelayanan merupakan konstruk penting yang mempengaruhi niat perilaku dari konsumen (Asmayadi, Hartini, 2015).

Ketatnya persaingan antara pasar-pasar yang mulai berkembang saat ini terutama pada pasar tradisional dan pasar modern tidak sedikit produsen yang terlibat dalam setiap pemenuhan kebutuhan maupun keinginan konsumen yang membuat setiap pengusaha harus bisa menempatakan kepuasan konsumen sebagai tujuan utamanya, sehingga semakin banyaknya produk ataupun jasa yang ditawarkan maka akan semakin banyak juga pilihan konsumen untuk menentukan jadi atau tidaknya suatu pembelian barang maupun jasa (Yoestini, 2015).

Survei awal yang dilakukan di Pasar Gedhe Solo didapat dari sumber Dinas Pengelola pasar yang menyatakan bahwa ada indikasi Pasar Gedhe Solo mengalami penurunan konsumen dilihat dari berkurangnyanya kunjungan dari konsumen yang berbelanja di pasar dan juga diperoleh indikasi penurunan konsumen dari wawancara dengan para pedagang yang ada di Pasar Gedhe Solo dilihat dari pendapatan para pedagang yang sedikit menurun daripada tahun sebelumnya. Pengelola pasar juga menyatakan terjadi kenaikan konsumen ketika menjelang hari besar tertentu atau Hari Raya ini dikarenakan masyarakat banyak membeli keperluan untuk kebutuhan hari raya dan hari besar tertentu

Berdasarkan uraian dan latar belakang diatas, menjadi pertimbangan peniliti untuk membahas lebih lanjut dan melakukan penelitian mengenai kulitas produk, diversifikasi produk, dan kualitas pelayanan terhadap loyalitas pelanggan. Dengan ini peneliti berpendapat bahwa layak melakukan penelitian dengan judul : Analisis Kualitas Produk, Diversifikasi Produk dan Kualitas Pelayanan Terhadap Loyalitas Pelanggan (studi kasus di Pasar Gedhe Solo).

Tujuan penulisan ini adalah Menganalisa pengaruh secara simultan kualitas produk, diversifikasi produk dan kualitas pelayanan terhadap loyalitas pelanggan di pasar Gedhe Solo, Menganalisa pengaruh kualitas produk terhadap loyalitas pelanggan di pasarGedheSolo, Menganalisa pengaruh diversifikasi produk terhadap loyalitas pelanggan di pasar Gedhe Solo dan Menganalisa pengaruh kualitas pelayan terhadap loyalitas pelanggan di pasar Gedhe Solo. 


\section{KAJIAN PUSTAKA}

\section{a. Loyalitas Pelanggan}

Loyalitas merupakan keadaan psikologis maupun perilaku dari seorang konsumen yang berhubungan erat dengan sikap terhadap suatu produk maupun jasa dari produsen dan penyedia jasa dan meyakinkan konsumen untuk suka maupun tidak suka dan melakukan pembelian ulang atau tidak terhadap suatu produk (Yulia dan Hardi, 2017)

Kategori Loyalitas Pelanggan

Menurut Kotler danAmstrong(2010) loyalitas pelanggan dikategorikanmenjadi 4 kategori yaitu :Loyals hardcore,Loyals softcore,Shifting loyal dan Switcher.

IndikatorLoyalitas Pelanggan

Menurut Kotler \& Keller (2012:57) yaitu:RepeatPurchase,Retention,Referalls.

\section{b. Kualitas Produk}

Kualitas produk merupakan kemampuan dari sebuah produk dalam melakukan sebagaimana fungsinya, dalam hal ini termasuk keseluruhan durabilitas, reabilitas, ketetapan, kemudahan pengoperasian dan reparasi produk juga atribut produk lainnya (Kotler dan Amstrong, 2012:283)

\section{c. Diversifikasi Produk}

Upaya mencari dan mengembangkan produk atau pasar baru, atau keduanya dalam rangka mengejar pertumbuhan, peningkatan penjualan, profitabilitas dan fleksibilitas (Tjiptono, 2008: 132).

Ada 4 indikator dari keberagaman produk (Nurrohman, Minarsih dan Warso, 2016) yaitu: Kelengkapan dari produk yang dijual, Jenis produk yang bervariasi, Ketersediaan produk yang dijualdan Macam merk yang dijual

\section{d. Kualitas Pelayanan}

Loyalitas muncul atas dasar kepuasan, karena kepuasan mempunyai pengaruh yang positif terhadap loyalitas maka dari itu apabila konsumen puas dengan kualitas pelayanan yang diberikan produsen maupun penyedia jasa maka smakin loyal juga para pelanggan terhadap pembelian produk nya dan akan melakukan pembelian ulang atas produk atau jasa tersebut (Ariyanti, 2010). Indikator dari kepuasan pelanggan tersebut yaitu: Tangibles (bukti langsung) yaitu meliputi fasilitas fisik, perlengkapan,pegawai, dan sarana komunikasi, Reliability (kehandalan) yaitu kemampuan dalam memberikan pelayanan dengan segera dan memuaskan serta sesuai dengan yang telah dijanjikan,Responsiveness (daya tangkap) yaitu keinginan para staf untuk membantu para pelanggan dan memberikan pelayanan dengan tanggap , Assurance (jaminan) yaitu mencakup kemampuan, kesopanan dan sifat dapat dipercaya yang dimiliki para staf, bebas dari bahaya, resiko atau keraguraguan dan Empati yaitu meliputi kemudahan dalam melakukan hubungan, komunikasi yang baik dan perhatian dengan tulus terhadap kebutuhan pelanggan.

\section{METODE PENELITIAN}

Jenis penelitian ini menggunakan metode deskriptif dengan pendekatan kuantitatif. Populasi dalam penelitian ini adalah seluruh konsumen yang berbelanja kebutuhan sehariharinya di pasar Gedhe Solo yang jumlahnya tak terhingga dengan menggunakan teknik sampling convinience sampling. Sampel yang diambil sebanyak 100 responden. Metode analisis data yang digunakan adalah regresi linier berganda. 


\section{ANALISIS DATA DAN PEMBAHASAN}

Uji Normalitas

Hasil0,10 dan VIF<10,0 pengujian ini menunjukkan bahwa nilai Asymp. Sig (2-tiled) 0,812 atau lebih besar dari 0,05 maka dapat disimpulkan bahwa persamaan regresi untuk model dalam penelitian ini memiliki data yang normal.

\section{Uji Multikolinearitas}

Uji multikoliniearitas dilakukan untuk mengetahui apakah terdapat korelasi antar variabel bebas, apabila nilai tolerance $>.0,10$ dan $\mathrm{VIF}<10,0$

\begin{tabular}{|l|l|l|l|}
\hline Variabel & Tolerance & & VIF \\
\hline Kualitas Produk & 0,972 & 1,028 & Tidak Terjadi Multikolinearitas \\
\hline Diversifikasi Produk & 0,682 & 1,466 & Tidak Terjadi Multikolinearitas \\
\hline Kualitas Pelayanan & 0,671 & 1,490 & Tidak Terjadi Multikolinearitas \\
\hline
\end{tabular}

\section{Uji Heterokedastisitas}

Uji ini dapat dilakukan dengan cara uji gletser, yaitu meregres nilai absolut residual terhadap variabel bebas. Jika Pvalue > 0,05 maka tidak terjadi heterokedastisitas, sebaliknya jika Pvalue < 0,05 maka terjadi heterokedastisitas

\begin{tabular}{|l|l|l|l|}
\hline Variabel & Sig & Batas & Keterangan \\
\hline Kualitas Produk & 0,122 & $>0,05$ & Tidak Terjadi Heterokedastisitas \\
\hline Diversifikasi Produk & 0,700 & $>0,05 \mathrm{y}$ & Tidak Terjadi Heterokedastisitas \\
\hline Kualitas Pelayanan & 0,558 & $>0,05$ & Tidak Terjadi Heterokedastisitas \\
\hline
\end{tabular}

Berdasarkan data tabel diatas dapat disimpulkan bahwa probabilitas value $\mathrm{X}_{1}, \mathrm{X}_{2}$, dan $\mathrm{X}_{3}$ lebih besar dari 0,05yang berarti tidak signifikan, sehingga dapat diartikan bahwa data berasal dari varians sama dan tidak terjadi heterokedastisitas.

\section{Analisis Regresi Linier Berganda}

\begin{tabular}{|l|l|l|}
\hline \multirow{2}{*}{ Model } & \multicolumn{2}{|l|}{ Unstandardized coefficients } \\
\cline { 2 - 3 } & B & Std.Eror \\
\hline (Constantant) & & \\
Kualitas Produk & 67.130 & 3.698 \\
Diversifikasi Produk & -0.677 & 0.089 \\
Kualitas Pelayanan & -0.211 & 0.075 \\
& -0.364 & 0.082 \\
\hline
\end{tabular}

Maka dapat disusun analisis regresi sebagai berikut:

$\mathrm{Y}=67.130+(-0.677)+(-0.211)+(-0.364)+\mathrm{e}$

\section{Uji Hipotesis}

\section{Uji F}

Uji $F$ digunakan untuk mengetahui apakah variabel independen secara bersama-sama (simultan) memiliki pengaruh signifikan baik positif maupun negatif terhadap variabel dependen. Menurut hasil maka diketahui nilai $\mathrm{F}$ hitung > F tabel $(34,160>2,70)$ dan signifikansi $0,000<$ 0,05 maka Ho ditolak. Kesimpulan bahwa kualitas produk, diversifikasi produk, dan kualitas 
pelayanan berpengaruh secara simultan signifikan terhadap loyalitas pelanggan pasar Gedhe Solo.

Uji t

\begin{tabular}{llll}
\hline Variabel & $\mathrm{T}_{\text {hitung }}$ & $\mathrm{T}_{\text {tabel }}$ & Sig \\
\hline Kualitas Produk & -7.565 & 1.98498 & 0.000 \\
Diversifikasi Produk & -2.814 & 1.98498 & 0.006 \\
Kualitas Pelayanan & -4.452 & 1.98498 & 0.000 \\
\hline
\end{tabular}

Variabel Kualitas Produk nilai t hitung -7.565 dengan signifikansi 0,000 maka Ho ditolak, Variabel Diversifikasi Produk nilai t hitung -2.814 dengan signifikansi 0.006 maka Ho ditolak dan Kualitas Pelayanan nilai t hitung -4.452 dengan signifikansi 0.000 maka Ho ditolak

Koefisien Determinasi $\left(\mathbf{R}^{2}\right)$

Nilai R2 sebesar 0,505 atau 50,5\% artinya bahwa variabelKualitas produk, diversifikasi produk, dan kualitas pelayanan memiliki pengaruh sebesar 50,5\% terhadap loyalitas pelanggan pasar Gedhe Solo sisanya 49,5\% dipengaruhi oleh variabel lain di luar penelitian ini.

\section{Pembahasan}

Berdasarkan hasil penelitian tentang "analisis kualitas produk, diversifikasi produk dan kualitas pelayanan terhadap loyalitas pelanggan di pasar gedhe solo" diperoleh sebagai berikut :

\section{Pengaruh Kualitas Produk, Diversifikasi Produk Dan Kualitas Pelayanan Secara Simultan Terhadap Loyalitas Pelanggan}

Kualitas produk, diversifikasi produk dan kualitas pelayanan berpengaruh secara simultan dan signifikan terhadap loyalitas pelanggan di pasar gedhe solo karena memiliki nilai signifikansi yang lebih rendah dari level of significant 0.05

\section{Pengaruh Kualitas Produk Terhadap Loyalitas Pelanggan}

Kualitas produk berpengaruh negatif dan signifikan terhadap loyalitas pelanggan di pasar Gedhe Solo. Hal ini menunjukan bahwa kenaikan kualitas produk tidak menjadikan meningkatnya loyalitas pelanggan, seperti pada produk yang memiliki kualitas yang sangat baik dan sangat layak dapat menimbulkan kenaikan harga yang menyebabkan pelanggan menjadi tidak loyal terhadap produk yang dijual di Pasar Gedhe Solo dan berpindah ke pasar lain yang memiliki kualitas sama namun dengan harga yang lebih murah.

\section{Pengaruh Diversifikasi Produk Terhadap Loyalitas Pelanggan}

Disversifikasi produk berpengaruh negatif dan signifikan terhadap loyalitas pelanggan di pasar Gedhe Solo.Hal ini menunjukan bahwa kenaikan diversifikasi produk tidak menjadikan meningkatnya loyalitas pelanggan, seperti pada ragam produk keluaran baru tidak menjadikan para pelanggan loyal terhadap produk yang dijual di pasar gedhe solo dimana pasar gedhe popular dengan grosir sayur dan buah juga jajanan pasar nya sehingga produk keluaran baru tidak menjadikan pelanggan loyal.

\section{Pengaruh Kualitas Pelayanan Terhadap Loyalitas Pelanggan}

Kualitas pelayanan berpengaruh negatif dan signifikan terhadap loyalitas pelanggan di pasar Gedhe Solo, Kepuasan pelayanan seperti kerapian maupun kebersihan dari pedagang yang ada di pasar gedhe solo tidak menjadikan pelanggan loyal terhadap produk yang dijual di pasar gedhe solo karena konsumen lebih memperhatikan produk atau barang yang dijual di pasar gedhe solo daripada kerapihan maupun kebersihan dari pedagangnya

\section{KESIMPULAN}

Kualitas produk, diversifikasi produk dan kualitas pelayanan berpengaruh secara simultan dan signifikan terhadap loyalitas pelanggan di pasar Gedhe Solo, Kualitas produk berpengaruh Negatif signifikan terhadap loyalitas pelanggan di pasar Gedhe Solo, Disversifikasi produk berpengaruh negatif signifikan terhadap loyalitas pelanggan di pasar 
Gedhe Solo, Kualitas pelayananberpengaruh negatif signifikan terhadap loyalitas pelanggan di pasar Gedhe Solo

\section{DAFTAR PUSTAKA}

Amri, S, \&Yoestini, Y. (2015). Analisis Pengaruh Kualitas Produk, KebersihanDan Kenyamanan Di Pasar Tradisional Terhadap Perpindahan BerbelanjaDari Pasar Tradisional Ke Pasar modern Di Kota Semarang (DoctoralDissertation, Fakultas Ekonomika Dan Bisnis).https://eprints.undip.ac.id

Arianty, Nel. (2013). Analisis Perbedaan Pasar Modern dan Pasar Tradisionalditinjau dari Strategi Tata Letak dan Kualitas Pelayanan. JurnalManajemen dan Bisnis, Vol. 13.https://jurnal.umsu.ac.id

Bulan, T, P, L. (2017). "Pengaruh Diversifikasi Produk dan Harga terhadap KepuasanKonsumenpadaJuraganJasmineLangsa.vol.6.No.1.https://ejurnalunsam.id

Hendra Fure, (2013).Lokasi, Keberagaman Produk, Harga, dan KualitasPelayanan Pengaruhnya Terhadap Minat Beli pada Pasar TraditionalBersehati Calaca, Jurnal EMBA, Vol.1 No.3.https://ejournal.unsrat.ac.id

Hurriyati, Ratih. (2015). Bauran Pemasaran dan Loyalitas Konsumen.Bandung:ALFABETHA Kotler dan keller. (2012). Manajemen pemasaran.Edisi:12.Jakarta:Erlangga

Kotler, Philip and Keller, Kevin Lane (2013), Manajemen Pemasaran, Jilid 1, Edisi:13,Jakarta: Erlangga.

Kotler, Philip dan Gary Armstrong. (2010). Principles of Marketing (Edisi 13). United State Of America:Pearson

Lucius,Hermawan. (2015). "Dilema Diversifikasi Produk : Meningkatkan Pendapatan Atau MenimbulkanKanibalisme Produk. Vol. 9, No. 2, Oktober 2015.https://jurnal.trunojoyo.ac.id

Maryam, Siti. 2015.Statistik Induktif.Surakarta: UNIBA press

Mongkau Gladis,Lotje Kawet,Jantje Sepang.(2017), Pengaruh Kualitas Produk, Harga, Dan Tempat Terhadap Kepuasan Konsumen Pada Pasar Tradidional Remboken (Studi Kasus pada Masyarakat Desa Sinuian Kec.Remboken) . Vol.5 No.2 Juni 2017, Hal.24692477.https://ejournal.unsrat.ac.id

Nurrohman, dan Maria M. Minarsih, Moh. Mukeri Warso. 2016. AnalisisPengaruh Letak, Variasi Produk dan Lingkungan Fisik TerhadapLoyalitas Konsumen (Studi Kasus PD. Pasar Gayamsari Semarang).Journal Of Management, Volume 2 No.2 Maret 2016. Semarang:Universitas Pandanaran

Oenaryo, Anastasya Audrey. Liza, A, M, N. (2013). Shoopers loyalty in Pasar Dukuh Manunggal Surabaya.Vol.15 No.1.https://jurnalmanajemen.petra.ac.id

PramudyoAnung. (2015). Pengaruh Kualitas Pelayanan Terhadap Loyalitas Masyarakat Berbelanja Pada Pasar Tradisional di Kabupaten Bantul. Akademi Manajemen Administrasi YPK

Putri, Y, L. Hardi Utomo. (2017). Pengaruh Kualitas Pelayanan Terhadap Loyalitas Pelanggan Dengan Kepuasan Sebagai Variabel Intervening (Studi persepsi Pada Pelanggan Dian Comp Ambarawa). Vol.10.No.19.https://jurnal.stieama.ac.id 
Rasmulia, Sembiring. 2016. Pengaruh Harga, Kualitas, Keragaman Produk danLokasi Pasar Terhadap Preferensi Konsumen Dalam Membeli ProdukPertanian di Pasar Tradisional Berastagi. Agrica Jurnal: Agribisnis SumateraUtara Vol.9 No.2.https://ojs.uma.ac.id

Santoso, Singgih. 2012. Panduan Lengkap SPSS Versi 20. Jakarta: PT Elex MediaKomputindo

Saodah dedeh siti dan Malia rosda. 2017, “ Faktor-Faktor Yang Mempengaruhi KonsumenDalam Pembelian Sayuran Di Pasar Tradisional (Studi Kasus Pasar Muka Cianjur)".Jurnal Agroscience Vol. 7

Saputra , A. \& Mareta, G. (2015). Pengaruh Lokasi, Kualitas Produk dan Kualitas Pelayanan Terhadap kepuasan Konsumen Pasar Tradisional (studi kasus Pasar Tradisional di Kecamatan Medan Johor). Volume 23 No.1 Januari 2015.https://osf.io

Tarida, Yuni. 2012. "Startegi Diferensiasi Produk, Diversifikasi Produk, HargaJual, dan Kaitannya Terhadap Penjualan pada Industri Kerajinan Rotandi Kota Palembang”. Jurnal Ekonomi dan Pembangunan. Vol. 10. No. 2.https://ejournal.unsri.ac.id

Tjiptono, Fandy. 2008. Strategi Pemasaran, Edisi Ketiga. Andi, Yogyakarta

Yuanita,Nova.(2008).”Analisis Pengaruh Keunggulan Produk dan kualitas Layanan Terhadap Loyalitas Pelanggan Speedy . Vol. 7. No3 . https : //ejurnalundip.ac.id

Zainul Arif Achmad.(2017), Pengaruh Keragaman Produk, Kualitas Produk, Harga dan Lokasi Terhadap Minat Beli Konsumen di Pasar Surabaya.http://karyailmiah.narotama.ac.id/files 